\title{
Geochemical Characterization of Rain Water Particulate Material on a Coastal Sub-Tropical Region in SE - Brazil
}

\author{
E.V. Silva Filho ${ }^{\mathrm{a}}$, R.P. Paiva ${ }^{\mathrm{b}}$, J.C. Wasserman ${ }^{\mathrm{a}}$, and L.D. Lacerda ${ }^{\mathrm{a}}$ \\ ${ }^{\mathrm{a}}$ Depto de Geoquímica, Universidade Federal Fluminense, \\ 24020-150 Niterói - RJ, Brazil \\ ${ }^{\mathrm{b}}$ Instituto de Pesquisas Energéticas e Nucleares, IPEN/CNEN, São Paulo - SP, Brazil
}

Received: December 9, 1997

\begin{abstract}
Um grande número de publicações tem focalizado o aspecto da contaminação do material particulado atmosférico em regiões temperadas. Entretanto pouco se conhece sobre o assunto nos países tropicais, principalmente aqueles em desenvolvimento. Esse trabalho faz uma caracterização do material particulado atmosférico coletado junto com a chuva, em dois locais no litoral do Estado do Rio de Janeiro: o primeiro em Sepetiba sujeito a elevada deposição atmosférica de metais devido à atividades industriais, e o segundo (Iguaba na Região dos Lagos) sujeito apenas a intensa atividade turística e de urbanização. O material particulado, obtido da filtração de amostras de chuva, foi analisado por ativação de nêutrons. Os resultados mostram três importantes constatações: 1) o fator de enriquecimento separa os elementos em dois grupos, um com origem na crosta e outro antropogênico; 2) a grande uniformidade na deposição da maioria dos elementos; e 3 ) o enriquecimento de elementos no particulado atmosférico pode constituir-se numa fonte importante de contaminantes para solos, sedimentos e para o ambiente marinho.
\end{abstract}

\begin{abstract}
Airborne contamination has been of concern for a number of scientist in temperate regions. In the tropics, a very small amount of data is available. In this work, rain water particulate material was monitored in two sites in Rio de Janeiro State (Brazil): the first (Sepetiba), subjected to high inputs of metals from industrial activities and the second (Iguaba), subjected to very mild contamination. Particulate material was obtained by filtration of rain water samples. The filters were analysed by instrumental neutron activation analysis. The results show three important features: 1) the element enrichment patterns could be split into two groups, crustal and anthropogenic derived; 2) uniformity of element loads in rain water particles is observed; 3) enrichment of certain trace elements in airborne particles is probably an important source of contaminants to soils, sediments and the marine environment.
\end{abstract}

Keywords: rain water particulate matter, trace metals, coastal region, SE Brazil

\section{Introduction}

Atmospheric inputs of trace metals in coastal areas have been the subject of a number of recent investigations, particularly in temperate regions ${ }^{1}$ and to a lesser extent, in tropical areas $2,3,4$.

The State of Rio de Janeiro is the second most important industrial and urban area in Brazil, with about 14 million inhabitants living within the metropolitan region of Rio de Janeiro. In the last three decades industrial, tourism and urban expansion have been very intensive, leading to a series of environmental impacts. The southern most part of the metrpolitan area, which includes the Sepetiba basin, shows the fastest growing rates of industrialization and urbanization, due to transportation facilities (roads and railways), cheap and extensive available land and good freshwater supply. Large population flows and the construction of a large harbour in the early 70's made the area more attractive for industrial development. Currently, there are over 400 industries, mostly: pyrometalurgic, including two large steel plants, an aluminum plant and thermal 
oil-fired power plant. This industrial park is responsible for the input of large amounts of heavy metals into the surrounding environment, reaching the coastal region by rivers or through atmospheric deposition ${ }^{4,5}$.

The Iguaba Municipality is located approximately 100 $\mathrm{km}$ north of Rio de Janeiro city, it has developed into an important tourist area where natural beachs and lagoons represent an attraction for summer vacations. The population of this area doubles during the summer season. No industrial activities are present in this area except salt extration from the lagoons. The main trace metal sources in this area are domestic wastes and urban runoff, although significant inputs of $\mathrm{Pb}$ were recorded from the atmospheric deposition ${ }^{6}$.

Although the chemistry of rain water has been the subject of a number of studies, the associated particulate material has been virtually ignored, for example, this fraction of the atmospheric deposition, can be significant, in particular in coastal regions ${ }^{7}$. Duce and Hoffman ${ }^{8}$ concluded that the rainfall deposition of particles is about twice as great as the dry deposition whereas Keeler et al. ${ }^{9}$, suggested that at least for some trace metals, the particulate phase may dominate the bulk atmospheric deposition. Also, atmospheric particle deposition is responsible for a considerable scavenging of trace metals, resulting in their deposition relatively close $(<100 \mathrm{~km})$ to their sources ${ }^{10}$. Due to the importance of particulate material in rain water chemistry, two regions (Sepetiba, $60 \mathrm{~km}$ to the south and Iguaba $100 \mathrm{~km}$ to the north of the Rio de Janeiro city) were chosen to investigate trace element contents in particulate material. Collectors from rain sample sites are shown in Fig. 1.

\section{Materials and Methods}

Both stations of rain water sampling were located close to shore, the rain water samplers were equipped with an acrylic funnel (collection area of $0.0625 \mathrm{~m}^{2}$ ) and a polyethylene plastic bucket attached to a narrow end. The samplers were fixed at a height of $1.5 \mathrm{~m}$ above the ground. The collector provides bulk samples (wet and dry deposition). All devices used for sampling were pre-cleaned with

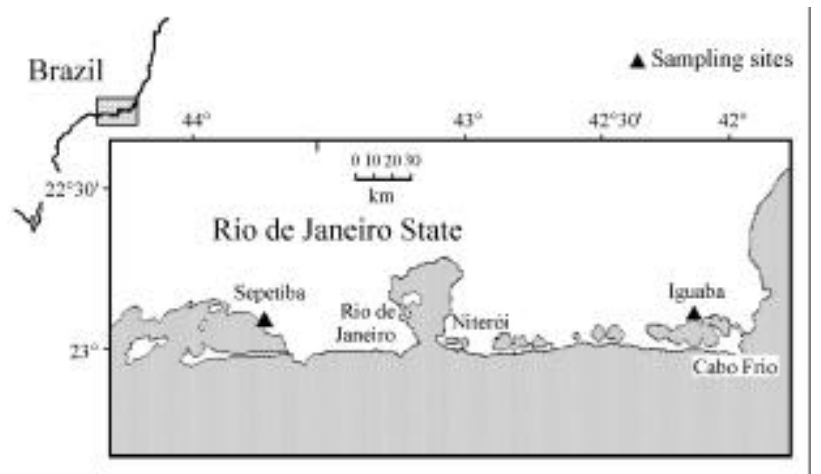

Figure 1. Location of sampling stations. metal-free acids and distilled water (Milli-Q) and the samples were collected using the standard procedures (National Atmospheric Deposition Program) ${ }^{11}$.

Rain water samples were collected monthly during a period of one year, from August 1993 to August 1994. Except in February at Iguaba, since atipically, no rain was recorded during that month.

After the mesurement of the total volume, rain samples were filtered through acid pre-washed and pre-weighed $0.45 \mu \mathrm{m}$ Millipore ${ }^{\circledR}$ membranes (47 mm diameter), dried for 1 week at room temperature in a laminar flow hood and weighed.

The particles elemental concentration was determined by instrumental neutron activation analysis (INAA).

Membranes, folded into precleaned polyethylene bags, and elemental standards were irradiated for $5 \mathrm{~min}$ (to determine $\mathrm{Al}, \mathrm{Mn}, \mathrm{Na}, \mathrm{Ti}$ and $\mathrm{V}$ ) and for $8 \mathrm{~h}$ (to determine As, Ba, Ca, Co, Cr, Fe, K, La, Sm, Th and Zn) under a thermal neutron flux of $10^{12} \mathrm{n} \mathrm{cm}^{-2} \mathrm{~s}^{-1}$ at the IEA-R1 nuclear reactor of the IPEN-CNEN/SP. Measurements of gamma rays induced in samples and standards were carried out in an hyperpure Ge detector after different decay times. Spectra analysis were carried out using the VISPECT software developed at IPEN-CNEN/SP. Two reference materials: Coal Fly Ash (ICHTJ-CTA-FFA-1) and Urban Particulate Matter (NBS-SRM-1648), were analysed in order to check the precision and accuracy of the method. Results obtained and certified values are presented in Table 1. The accuracy and precision are higher than $90 \%$ for most of the elements. Membrane blanks were treated as particulate samples and routinely run during the analysis in order to check sample contamination.

\section{Results and Discussion}

Table 2 shows the annual precipitation and the result of the gravimetric measurements of the particulate mass at the two sites. The results show that the total particulate mass deposition in Sepetiba is three times higher than those in Iguaba.

Figure 2 shows the fluxes of trace elements in the particulate material. A qualitative examination reveals that in the industrial region (Sepetiba) the concentrations of Fe, Al, Mn, Zn, Ti, Na, K, Ca, Mg, As, Ba, Co, W, Cs and Th are higher than those observed at Iguaba. For the elements (Fig. 2a) Fe, Al, Mn, Zn, Ti, Na, Mg, Ca, K and $\mathrm{Ba}$ deposition fluxes in Sepetiba were 2 to 3 times higher than in Iguaba, suggesting that the increase in total particulated mass deposition (Table 2), is responsible for the observed increase. For the elements, As, Cr, Co, Sm, Th, La, Cs and W (Fig. 2b) deposition fluxes in Sepetiba were one to two orders of magnitude higher. On the other hand, vanadium fluxes in Iguaba are three orders of magnitude higher than in Sepetiba. These large differences may be explained by 
Table 1. Certified values and elemental concentration obtained for Urban Particulate Matter (NBS-SRM-1648) and Coal Fly Ash (ICHTJ-CTA-FFA-1) reference materials.

\begin{tabular}{lcccccc}
\hline & & \multicolumn{3}{c}{ NBS-SRM-1648 } & \multicolumn{2}{c}{ ICHTJ-CTA-AFFA-1 } \\
\hline Element & Concentration unit & This work & Certificate, 1978 & Greenberg, $1979^{12}$ & This work & IAEA, 1995 \\
\hline $\mathrm{Al}$ & $\%$ & $3.24 \pm 0.06$ & $3.42 \pm 0.11$ & $3.5 \pm 0.1$ & $14 \pm 2$ & $14.87 \pm 0.39$ \\
$\mathrm{As}$ & $\mu \mathrm{g} \mathrm{g}^{-1}$ & $114.5 \pm 0.7$ & $115 \pm 10$ & $117 \pm 5$ & - & - \\
$\mathrm{Ba}$ & $\mu \mathrm{g} \mathrm{g}^{-1}$ & $736 \pm 74$ & 737 & $740 \pm 60$ & $860 \pm 18$ & $835 \pm 56$ \\
$\mathrm{Ca}$ & $\%$ & $5.5 \pm 0.4$ & - & $5.8 \pm 0.5$ & - & - \\
$\mathrm{Co}$ & $\mu \mathrm{g} \mathrm{g}^{-1}$ & $17.4 \pm 1.1$ & 18 & $17.6 \pm 0.5$ & $39.7 \pm 0.5$ & $39.8 \pm 1.7$ \\
$\mathrm{Cr}$ & $\mu \mathrm{g} \mathrm{g}^{-1}$ & $370 \pm 24$ & $403 \pm 12$ & $402 \pm 10$ & $143 \pm 2$ & $156 \pm 8$ \\
$\mathrm{Fe}$ & $\%$ & $3.76 \pm 0.08$ & $3.91 \pm 0.10$ & $3.84 \pm 0.08$ & $4.82 \pm 0.08$ & $4.89 \pm 0.14$ \\
$\mathrm{~K}$ & $\%$ & $0.92 \pm 0.11$ & $1.05 \pm 0.01$ & $0.98 \pm 0.06$ & $2.12 \pm 0.05$ & 2.2 \\
$\mathrm{La}$ & $\mu \mathrm{g} \mathrm{g}^{-1}$ & - & - & - & $60.5 \pm 0.5$ & $60.7 \pm 4.0$ \\
$\mathrm{Mn}$ & $\mu \mathrm{g} \mathrm{g}^{-1}$ & $778 \pm 68$ & 860 & $790 \pm 20$ & $1073 \pm 37$ & $1066 \pm 40$ \\
$\mathrm{Na}$ & $\%$ & $0.40 \pm 0.02$ & $0.425 \pm 0.002$ & $0.40 \pm 0.02$ & - & - \\
$\mathrm{Sm}$ & $\mu \mathrm{g} \mathrm{g}^{-1}$ & $3.9 \pm 0.5$ & 4.4 & $4.0 \pm 0.4$ & $11.7 \pm 0.7$ & $10.9 \pm 0.55$ \\
$\mathrm{Th}$ & $\mu \mathrm{g} \mathrm{g}^{-1}$ & $6.4 \pm 0.5$ & 7.4 & $7.4 \pm 0.3$ & $28.3 \pm 0.6$ & $29.4 \pm 0.6$ \\
$\mathrm{Ti}$ & $\mu \mathrm{g} \mathrm{g}^{-1}$ & - & - & - & $5830 \pm 1095$ & 5800 \\
$\mathrm{~V}$ & $\mu \mathrm{g} \mathrm{g}^{-1}$ & $128 \pm 7$ & $140 \pm 3$ & $130 \pm 7$ & $267 \pm 20$ & $260 \pm 9.9$ \\
$\mathrm{Zn}$ & $\mu \mathrm{g} \mathrm{g}^{-1}$ & $460 \pm 20$ & $476 \pm 14$ & $470 \pm 20$ & - & $569 \pm 57$ \\
\hline
\end{tabular}

Table 2. Annual precipitation and total particulate mass deposition in Sepetiba and Iguaba.

\begin{tabular}{lcc}
\hline & Sepetiba & Iguaba \\
\hline Precipitation $\left(\mathrm{mm} \mathrm{year}^{-1}\right)$ & 1616 & 987 \\
Particles $\left(\mu \mathrm{g} \mathrm{cm}^{-2}\right.$ year $\left.^{-1}\right)$ & 2748 & 902 \\
\hline
\end{tabular}

different concentrations between particles from the two areas (Fig. 3).

The high variability in the atmospheric particulate concentrations of trace elements reflects the influence of constant changes in the atmospheric circulation conditions. This characteristic can be minimized by the use of histograms of these concentrations, normalized to the total particulate mass ${ }^{13}$. This normalization prevents significant variations in concentrations (Fig. 3). Four conclusions can be drawn from Figure 3:1) significant uniformity of concentration of the crustal elements (e.g.: $\mathrm{Al}, \mathrm{Fe}$ and marine aerosol derived elements; e.g. $\mathrm{Na}$ and $\mathrm{Mg}$ ) (Fig. 3a) in both areas; 2 ) the higher concentration of $\mathrm{Al}$ and $\mathrm{Fe}$ are consistent with the well-known dominance of these elements in a tropical environment ${ }^{14} ; 3$ ) there is a marked increase in concentration of industrial derived elements in Sepetiba, when compared to Iguaba (Fig. 3b); 4) vanadium presented a different pattern from all other elements with concentra-
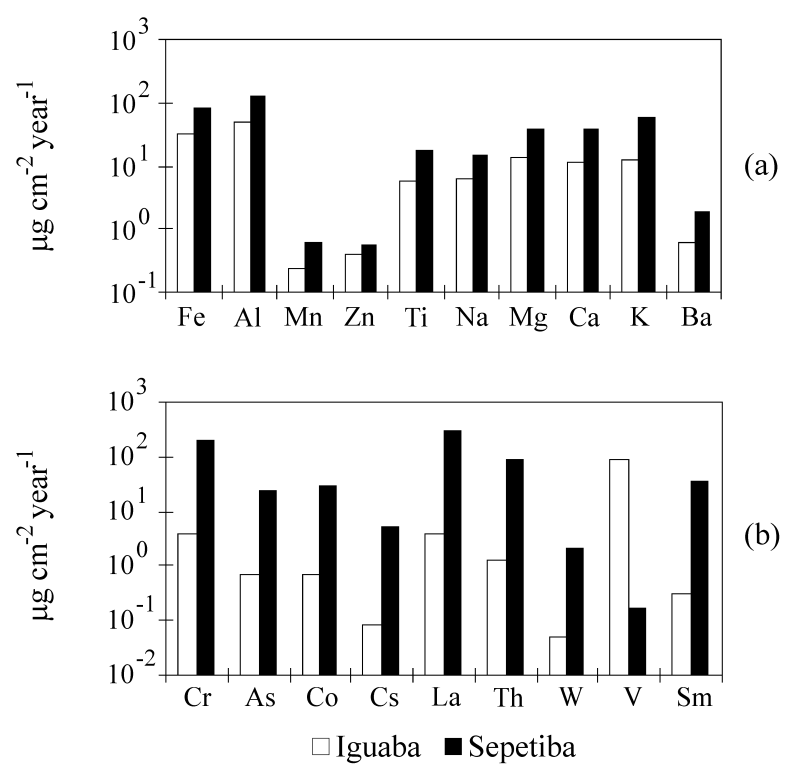

Figure 2. Annual deposition fluxes of trace-elements associated with rain particles over Iguaba and Sepetiba, SE Brazil.

tions and fluxes higher in Iguaba than in Sepetiba. No anthropogenic source of this element exists close to Iguaba. Although lithological background anomalies can not be ruled out as a contribution of $\mathrm{V}$ in the atmospheric particulate material, another explanation can be the enrichment of 
marine aerosols with remains of planktonic tunicates (Salpa spp.) particularly abundant in the upwelling waters off Iguaba ${ }^{15}$; which characteristically present an extremely high $\mathrm{V}$ concentration, of the order of $10^{6}$ times higher than sea water concentration, reaching over $1,000 \mu \mathrm{g} \mathrm{g}^{-1}$ of dried animal weight ${ }^{16}$. This sound hypothesis however, could not be tested here.

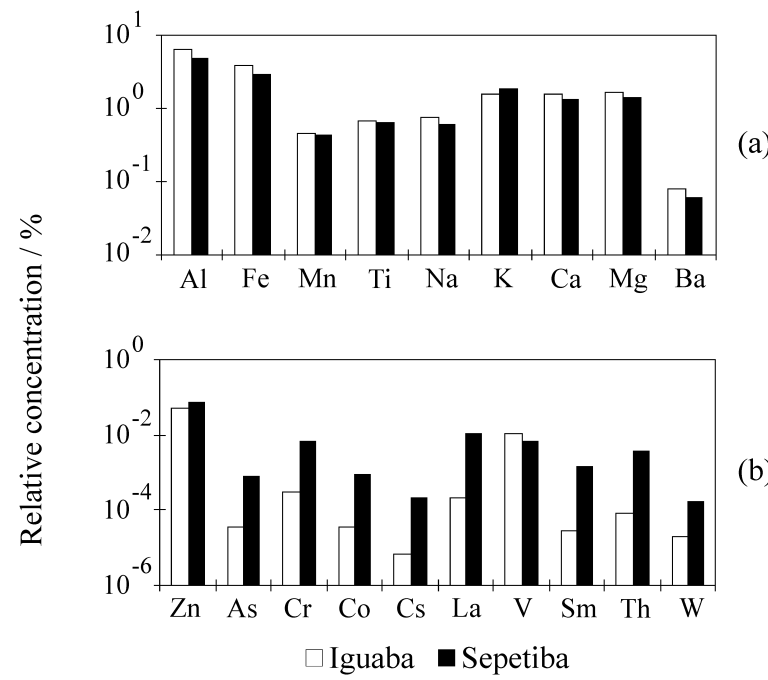

Figure 3. Histogram of the concentrations of trace-elements normalized by total particulate mass at Iguaba and Sepetiba, SE Brazil.
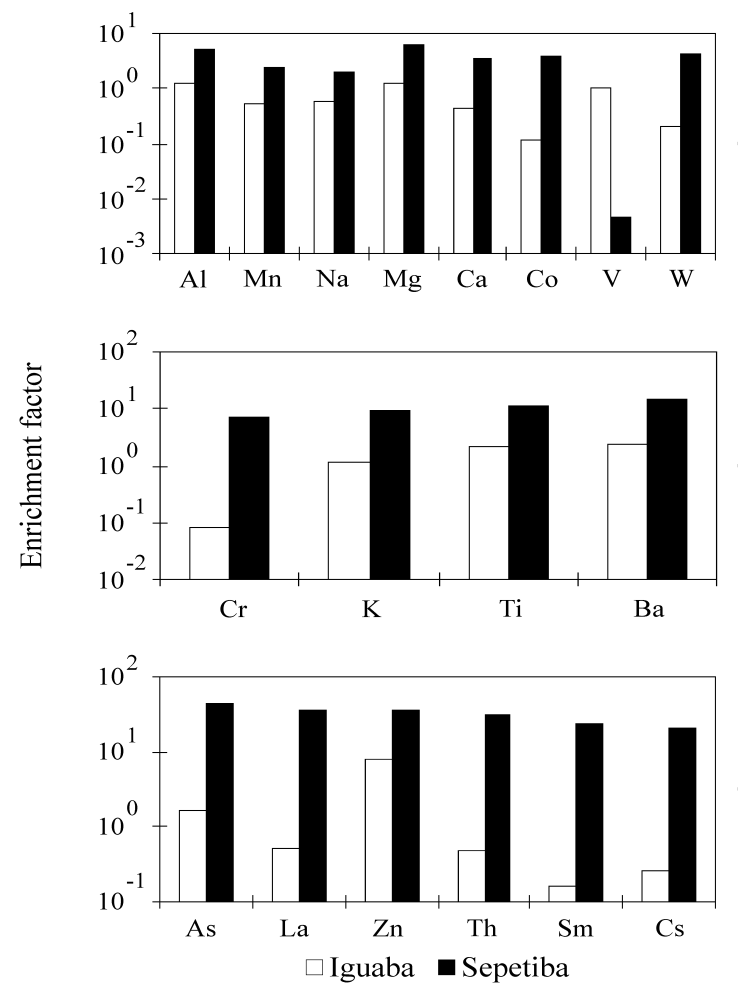

(c)

Figure 4. Enrichment factors for the rain water particulate material over Iguaba and Sepetiba, SE Brazil.
Enrichment factors can be used as a tool for determining the source (s) of aerosols. The enrichment factors used in this work are the ratio of the element with $\mathrm{Fe}$ in the particulate matter divided by the same ratio in the average crustal igneous rocks ${ }^{17}$. Most researchers agree that ratios greater than 10 are indicative of non-crustal sources, and values below 7 are indicative of soil source ${ }^{18}$. The mean enrichment factors of elements are shown in Fig. 4.

Elements such as $\mathrm{Al}, \mathrm{Mn}, \mathrm{Na}, \mathrm{Mg}, \mathrm{Ca}, \mathrm{V}, \mathrm{Co}$ and $\mathrm{W}$ were characterized by moderate enrichment values in both sites (enrichments between 0 and 3) (Fig. 4a).

Considering the significant element-element correlations, it is inferred that the particles originating from the earth crust and marine aerosols are the main sources for these elements in the atmosphere. In this group, $\mathrm{V}$ and $\mathrm{Co}$ could be originated from fossil fuel utilization from hightemperature combustion processes ${ }^{19}$ as in oil-fired (thermo-eletric plants) such as the Santa Cruz Plant. Rubber industry can also contribute with $\mathrm{Co}^{20}$. The other of element group presented is characterized by moderate enrichment, but different between the two sites, with higer enrichments in Sepetiba (Fig. 4b). Suggestting the influence of industrial activities. Chromium, Ti naturally enriched in Brazilian coals ${ }^{21}$ are probably associated with the presence of steel plants and pigment and paint production, in the Sepetiba region.

A third group of elements (Fig. 4c) are represented by As, Zn, Th and Rare Earth Elements (REE) with extremely high enrichment factors observed in Sepetiba. Arsenic is largely used in pyrometallurgical non-ferrous metal production $^{20,22}$. Barcellos et al. ${ }^{23}$ and Magalhães ${ }^{24}$ showed that a zinc and cadmium smelting plant, in Sepetiba, is also a major source of As to the environment. The source of Th and REE is probably associated with the coal combustion, which is supplied by Santa Catarina State and used in the reduction process of the Blast-furnace in the Sepetiba area.

\section{Conclusion}

This study has compared rain water particulate contents of elements in two sites from the Coastal region of the State of Rio de Janeiro - Brazil. First of all, Iguaba can be considered a remote region, without significant contamination from anthropogenic sources. In Sepetiba, the results show a clear separation of the studied elements into three classes, the "crustal and marine aerosol derived" ones, such as $\mathrm{Al}$ and $\mathrm{Na}$, having enrichment factors between 2 and 7 in the two sites, a second group with medium enrichment and, consistently higher in the Sepetiba site and a third group constituted by those elements mostly originating from anthropogenic (industrial) sources, with enrichment factors greater than 10. Another feature to be underlined is a remarkable small seasonal variation in the elemental composition of the rain water particulate. Our results suggest that the aerosol particles are one of the sources respon- 
sible for the element contamination of coastal areas of Rio de Janeiro State.

\section{References}

1. Waldichuk, M. Exchange of pollutants and other substances between the atmosphere and the oceans. In: The Handbook of environmental chemistry, O. Hutzinger, Ed., Springer Verlag, Berlin \& Heidelberg, 1988, vol.2, part 1, p.113-151.

2. Trindade, H.A.; Pfeiffer, W.C.; Londres, H.; CostaRibeiro, C.L. Atmospheric concentration of metals and total suspended particulates in Rio de Janeiro. Environmental Science \& Technology, Easton, 1981, v.15, n.1, p.84-89.

3. Oliveira, R.R.; Lacerda, L.D. Contaminação por chumbo na serrapilheira do Parque Nacional da Tijuca. Acta Bot. Bras. 1988, 1, 165-169.

4. Pedlowisk, M.A.; Lacerda, L.D.; Ovalle, A.R.C.; Watts, P.P.; Silva Filho, E.V. Atmospheric inputs of $\mathrm{Zn}, \mathrm{Fe}$ and Mn into Sepetiba Bay, Rio de Janeiro. Ciência e Cultura 1991, 43(5), 380-382.

5. Marins, R.V.; Silva Filho, E.V.; Lacerda, L.D. Atmospheric Deposition of Mercury over Sepetiba Bay, SE Brazil. J. Braz. Chem. Soc. 1996, 7, 177-180.

6. Patchineelam, S.R.; Leitão-Filho, C.M.; Kristotakis, K.; Tobschall, H.J. Atmospheric lead deposition into Guarapina Lagoon, Rio de Janeiro State, Brazil. In: Seeliger, U.; Lacerda, L.D.; Patchineelan, S.R., Eds., Metals in Coastal Environments of Latin America. Berlin, Springer-Verlag. 1988, 297 p. p. 65-74.

7. Haygarth, P.M.; Jones, K.C. Atmospheric deposition of metals to agricultural surfaces. In: Biogeochemistry of Trace Metals. Lewis Publishers, Adriano, D.C., Ed., Boca Raton, 1992. p. 249-276.

8. Duce, R.A.; Hoffman, G.L. Atmospheric vanadium transport to the ocean. Atmospheric Environment 1976, 10 (11), 989-996.

9. Keeler, G.; Glinsorn, G.; Pirrone, N. Particulate mercury in the atmosphere: Its significance, transport, transformation and sources. Water, Air, Soil \& Pollut. 1995, 80, 159.

10. Lindqvist, O. Ed. Mercury in the Swedish environment, mercury in terrestrial systems. Water Air Soil Pollut. 1991, 55(73):113-151.

11. Vermette, S.J.; Peden, M.E.; Willoughby, T.C.; Lindberg, S.E.; Weiss, A.D. Methodology for the sampling of metals in precipitation: Results of the National Atmospheric Deposition Program (NADP) Pilot Network. Atmospheric Environment 1995, 29(11), 12211229.

12. Geenberg, R. Trace element characterization of the NBS Urban Particulate Matter Standard Reference Material by Instrumental Neutron Activation Analysis. Anal. Chem. 1979, 51(2), 2004-2006.
13. Orsini, C.Q.; Netto, P.A.; Tabacniks, H. The São Paulo Pixe System and its use on a National Monitoring Air Quality Program. Nuclear Instruments and Method in Physics Research, 1984, B3 462-465.

14. Melfi, A.J.; Pedro, G. Estudo geoquímico dos solos e formações superficiais do Brasil. Parte 1 - Caracterização e repartição dos principais tipos de evolução pedogeoquímica. Revista Brasileira de Geociências 1977, 7, 271-286.

15. Valentin, J.L.; Monteiro-Ribas, W.M.; Mureb, M.A.; Pessoti, E. Sur Quelques zooplanctontes abondants dans l'wpwelling de Cabo Frio (Brésil). Journal of Plankton Research 1987, 9(6), 1195-1216.

16. Biggs, W.R.; Swinehart, J.H. Vanadium in selected biological systems. In: Metal ions in Biological Systems, Siegel, H., Ed., New York, 1976, Marcel Dekker, p. 141-196.

17. Rahn, K.A. The Chemical Composition of the atmospheric aerosol. Tech. Report, Grad. School of Oceanography, U. of R.I. Kingston, 1976, Rhode Island, U.S.A.

18. Servant, J. Atmospheric trace elements from natural and industrial sources. Prepared by Monitoring and Assessment Research Center, Chelsea College, University of London. 1982, 37 p.

19. Harrison, H.M.; Luhana, L.; Smith, D.J.T. Urban air pollution by heavy metals: Sources and trends. In: International Conference Heavy Metals in the Environment, v. 1, Toronto, 1993, p. 081-084.

20. Nriagu, J.O.; Pacyna, J.M. Quantitative assessment of worldwide contamination of air, water and soils by trace metals. Nature 1988, 333, 134-139.

21. Sanches, J.C.D.; Teixeira, E.C.; Fernandes, I.D.; Pestana, M.H.D.; Machado, R.P. Estudos da concentração e da mobilidade dos elementos metálicos nas cinzas da Usina Termoelétrica de Candiota. Geoquim. Bras. 1994, 8(1), 41-50.

22. Pacyna, J.M.; Munch, J. Atmospheric emissions of $\mathrm{As}, \mathrm{Cd}, \mathrm{Pb}$, and $\mathrm{Zn}$ from industrial sources in Europe. In: International Conference Heavy Metals in the Environment, v. 1, 1987, New Orleans, p. 20-25.

23. Barcellos, C.; Lacerda, L.D; Rezende, C.E.; Machado, J. Arsenic contamination in a coastal environment affected by a zinc smelting plant (Sepetiba Bay, Brazil). International Seminar: Arsenic in the Environment its Incidence on Health, 1992, Santiago, Proceedings...Santiago: Universidad de Chile, 1992. p. 59-62.

24. Magalhães, V.F. Contaminação Ambiental por Arsênio: o caso da Baía de Sepetiba, R.J. 1996, Rio de Janeiro, Brasil, 119f. , Doutorado em Biofísica, Universidade Federal do Rio de Janeiro. 